\title{
New Records of some Pests of the Coconut Inflorescence and Developing Fruit and Their Natural Enemies in Sri Lanka
}

\author{
L. C. P. FERNANDO and P. KANAGARATNAM \\ Coconut Research Institute, Lunuwila, Sri Lanka.
}

\begin{abstract}
A survey was carried out at Bandirippuwa Estate, Kirimetiyana Estate and at Isolated Seed Garden, Rajakadaluwa for the pests of coconut inflorescence and developing fruits.

The mite, Dolichotetranychus sp. (Tenuipalpidae) which lives beneath the perianth and feeds on the epicarp, causes considerable damage to the developing fruit. Bi-monthly observations on the intensity of infestation of nuts among different forms of coconut indicated a significant difference among forms in their susceptibility to mite damage.
\end{abstract}

Pseudococcus cocotis (Maskell) (Pseudococcidae), Pseudococcus citriculus Green (Pseudococcidae) and Planococcus lilacinus (Cockerell) (Pseudococcidae), when feeding in large numbers on the peduncle, cause button nut shedding and drying up of the inflorescence. The parasitoids and predators of these mealybugs recorded for the first time in Sri Lanka are Promuscidea unfasciativentris Girault (Aphelinidae) Platygaster sp. (Platygastridae), Anagyrus sp. nr. pseudococci (Girault) (Encyrtidae) Coccodiplosis sp. (Cecidomyiidae), Cryptogonus bryanti Kapur (Coccinellidae) and Pséudoscymnus sp. (Coccinellidae).

Several species of scale insects namely, Coccus hesperidum (Linnaeus) (Coccidae) Aulacaspis sp. (Diaspididae), Pseudaulacaspis cockerelli (Cooley) (Diaspididae), Aonidiella orientalis (Newstead) (Diaspididae), and Pinnaspis strachani (Cooley) (Diaspididae) are recorded as minor pests of the developing fruits of coconut. Coccophagus silvestrii Compere (Aphelinidae), Scymmus sp. (Coccinellidae), Pseudoscymnus sp. (Coccinellidae) Telsimia ceylonica (Weise) (Coccinellidae), Cryptogonus bryanti Kapur (Coccinellidae) and Cybocephalus sp. (Nitidulidae) are recorded as their parasitoids and predators. field.

These natural enemies are probably responsible for the control of these pests in the

\section{INTRODUCTION}

The coconut palm produces a large number of female flowers in each inflorescence but not all of them develop into mature fruits. Many drop prematurely due to nutritional, physiological or genetic factors or because of pest damage. Several important pests that cause damage to developing coconut fruits have been recorded in various countries. The caterpillars of Batrachedra arenosella Walker (Lepidoptera, Gelechiidae) and Tirathaba spp. (Lepidoptera, Pyralidae), the bugs Pseudotheraptus wayi Brown (Hemiptera, Coreidae), Amblypelta cocophaga China (Hemiptera, Coreidae) and Axiagastus cambelli Distant (Hemiptera, Pentatomidae) and the mite Eriophyes gurreronis (Acarina, Eriophyidae) are the best known pests of the inflorescence and nuts. 


\section{C. P. FERNANDO and P. KANAGARATNAM}

Caterpillars of $B$. arenosella and Tirathaba spp. feed on the young flowers of the newly opened inflorescence causing button nut shedding. B. aremosella and Tirathaba spp. occur in South East Asia and the Pacific. The feeding punctures made by the bugs, Pseudotheraptus wayi, Amblypelta cocophaga and Axiagastus cambelli cause deformity and premature nut fall. $P$. wayi is a serious pest of coconut in Tanzania, Kenya and Zanzibar (Lever, 1969). A. cocophaga causes about $10 \%$ crop loss in the Solomon Islands (Brown, 1959). It has several host plants other than coconut. A. cambelli feeds on both the male and female flowers and is found in the Solomon lslands and New Guinea. The eriophyid mite which lives under the perianth of developing fruits causes deformity and immature nut fall. It has been recorded from Ivory Coast, West Africa and Central and South America.

In Sri Lanka preliminary work on the survey and identification of mites, mealybugs and moths associated with the coconut inflorescence was carried out in 1981 (Kanagaratnam et/al., 1981). This stimulated further studies with regard to the distribution of pests, degree of damage and the occurrence of natural enemies. This study was carried out in the North Western Province at three selected locations: Bandirippuwa Estate, Lunuwila, Kirimetiyana Estate, Lunuwila and Isolated Seed Garden, Rajakadaluwa.

\section{THE TEXT}

A Tetranychid mite, mealybugs and scale insects were found on the inflorescence and the developing fruits.

The Dolichotetranychus sp. (Acarina, Tenuipalpidae) was first recorded on coconut by Kanagaratnam et. al. in 1981. The same mite was reported infesting the nuts of the areca palm in Kerala, (Mariamma and Kumar, 1976). This mite lives and multiplies under the perianth of the nut. It feeds on the sap of the epicarp around the point of attachment of the nut. The first symptom of attack is a brown patch at the base of the young nut at the level of the perianth. At this stage, when the perianth is lifted up, several aggregations of orange coloured mites, at all stages of development can be seen. Later these patcnes enlarge, the epidermis cracks, and occasionally deep fissures develop. Malformation of nuts, or immature nut drop, occurs if the infestation is severe.

The susceptibility of fifteen different forms of coconut to mite damage was observed from October 1984 to December 1985. The observations indicated that the association of mite damage among some forms were highly significant $(P<0.001)$ in comparison to other forms. The variety Nawasi showed the highest damage while Bodiri showed the lowest (Table 1).

\section{Mealybugs}

The mealybugs Pseudococcus cocotis (Maskell) (Hemiptera, Pseudococcidae), Planococcus lilacinus (Cockerell) (Hemiptera, Pseudococcidae) and Pseudococcus citriculus Green (Hemiptera, Pseudococcidae) are recorded for the first time on coconut inflorescence. These mealybugs mostly colonize the peduncle and stalk of the inflorescence, sometimes causing the inflorescence to dry up. Pseudococcus cocotis was the most common species observed in the two sites. Planococcus lilacinus has been recorded in 
Table 1. Percentage of harvested nuts damaged by mites in various varieties/forms of coconut from October 1984 to December 1985

\begin{tabular}{|c|c|}
\hline Name of varieties/forms. & Percent of nuts with mite damage \\
\hline Bodiri & 10.20 \\
\hline $\begin{array}{l}\text { Ranthambili, Pora pol Dwarf } \\
\text { Gon thambili }\end{array}$ & 20.30 \\
\hline $\begin{array}{l}\text { Kamandala, Rath ran thambi } \\
\text { Tall x Dwarf-hybrid }\end{array}$ & 30.40 \\
\hline $\begin{array}{l}\text { Nawasi thambili, Ordinary tal } \\
\text { San Ramon }\end{array}$ & 40.50 \\
\hline Nawasi, West African Form & 50 \\
\hline
\end{tabular}

Sri Lanka on Anona muricata and Theobroma cacao (Le Pelley, 1942). Pseudococcus citriculus was recorded from the leaves of coconut (Kanagaratnam et.al. 1981). The parasitoid Anagyrus sp. nr. pseudococci (Girault) (Hymenoptera: Encyrtidae), Promuscidia unfasciativentris Girault (Hymenoptera, Aphelinidae) and Platygaster.sp. (Hymenoptera, Platygastridae) emerged from the mealybug, Pseudococcus cocotis brought into the laboratory from the field. P. unfasciativentris was the most common parasitoid. Coccodiplosis sp. (Diptera; Cecidomiidae), Cryptogonus bryanti Kapur (Coleoptera, Coccinellidae and Pseudoscymonus sp. (Coleoptera, Coccinellidae) were found to be predators of these mealy bugs. Larvae of Cocodiplosis sp. pupate under the mealybug, or in close vicinity in a silken cocoon. The larvae were observed feeding on adult mealybugs. The host range of some of these natural enemies is very wide.

Known host range of the natural enemies of some mealybugs

Parasitoid/Predator

Anagyrus pseudococci

Promuscidea unfasciativentris

Pseudoscymorus sp.

Cryptogonus bryanti
Hosts

Planococcus citri, Rastrococcus iceryoidea Antonnia graminis

R. iceryoidea, Coccus viridis

Aspidiotus destructor

None.

\section{Seales}

Scale insects cause damage by sucking the sap of the palm and may be found on the leaves, nuts, and inflorescence. The scales Coccus hesperidum Linnaeus (Hemiptera, Coccidae), Aulacaspis sp. (Hemiptera, Diaspididae), Pseudaulacaspis cockerelli (Hemiptera; Diaspididae) and Aonidiella orientalis (Hemiptera, Diaspididae) were observed on the devoloping fruits and inflorescence of coconut. These scales are newly recorded in Sri Lanka.

Coccus hesperidum is yellow with an oblong shield and infests the nuts. It was hoavily parasitised by Coccophagus silvestrii Compere (Hymenoptera, Aphelinidae). Aulacaspis sp. and Pseudaulacaspis cockerelli (Hymenoptera;) are characterised by a white papery irregular shield. Cybocephalus sp. (Coleoptera, Coccinellidae) was observed preying on Aulacaspis sp., Aonidiella orientalis is orange with a round shield. It has a wide host range and has already been recorded from the fruits in India (Kapadia, 1981). 


\section{C. P. FERNANDO and P. KANAGARATNAM}

The beetles Scymmus (Pullus) sp. (Coleoptera, Coccinellidae), Cryptogonus bryantii Kapur (Coleoptera, Coccinellidae), Telsimia ceylonica (Coleoptera, Coccinellidae) and Pseudoscymnus sp (Coleoptera, Coccinellidae) were observed preying on these scale insects.

During the period of the survey, though mealybug and scale infestations were common at all the locations, they were not found on large number of palms. It is likely that the parasitoids and predators of these pests keep them under control.

\section{ACKNOWLEDGEMENT}

The authors are grateful to the C.A.B. International Institute of Entomology, London for the identification of the pests and their natural enemies.

\section{REFERENCES}

Brown, E. S. (1959). Immature nutfall of coconuts in the Solomon Islands. Bull. ent. Res. 49, 239-272.

Kanagaratnam, P., Pinto, J. L. J. G. and Sinnathamby, S. V. (1981. Some minor pests of coconut: New Record for Sri Lanka. Ceylon Cocon. Q. 32, 93-95.

Kapadia, M. N. (1981). New records of coconut scale insects and their natural enemies in Gujarat. Indian Coconut Journal. 12, 9-10.

Mariamma, D and Kumar, P. T. (1976). Pests of arecanut. Journal of Plantation Crops 4, 68-77.

Le Pelley, R. H. (1942). An oriental mealy bug Pseudococcus lilacinus (Ckll) (Hemiptera) and it's insect enemies. Trans. R. ent, Soc. Lond. 93, 73-93.

Lever, R. J. A. W. (1969). "Pests of the coconut palm". FAO Agricultural Studies. no. 77, Rome. 